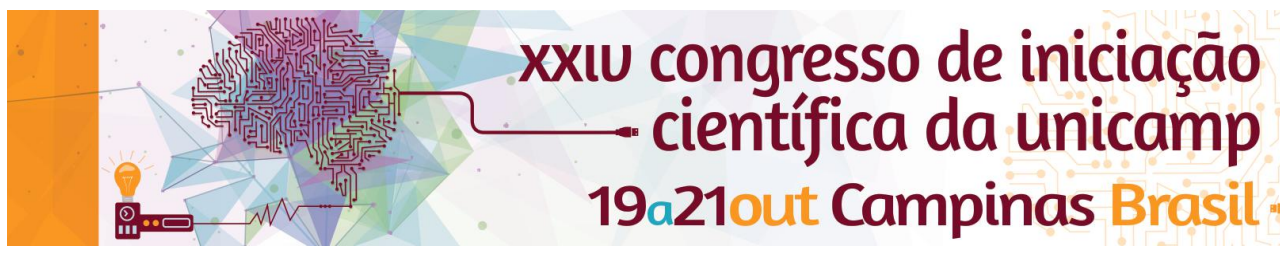

\title{
Avaliação de propriedades físicas de dentes bovinos clareados com agentes clareadores dopados com fosfatos de cálcio
}

\author{
Isabella Martin*, Gabriel Flores Abuna, Marcus Vinícius Bertolo Loureiro, Américo Bortolazzo Correr
}

\section{Resumo}

O presente estudo teve como objetivo avaliar as propriedades físicas de dentes bovinos que foram clareados com agentes clareadores modificados por fosfatos de cálcio. Para isso foram avaliados quatro grupos $(n=10)$ : Controleperóxido de hidrogênio 35\% (Whitening HP, FGM); HAP-10\% de hidroxiapatita;ACP-10\% de ACP; MACP-TCP-5\% de monocálcio fosfato e $5 \%$ de $\beta$ TCP. Avaliou-se a alteração da microdureza Knoop, rugosidade média através do rugosímetro e a cor $(\Delta \mathrm{E})$, utilizando o equipamento VITA EasyShade. Para isso, foi obtido uma leitura antes da aplicação do gel clareador, uma 24 horas após a aplicação do gel e outra após uma semana armazenada em saliva artificial, para cada amostra foram feitas três leituras e avaliado a média de cada uma.

\section{Palavras-chave:}

Claramento dental; Remineralização dentária; Cor

\section{Introdução}

O clareamento dental é um dos serviços mais requisitados aos cirurgiões dentistas diariamente. Existindo duas formas de realização, a caseira e a técnica realizada no consultório que utiliza elevadas concentrações de peróxido de hidrogênio. O principal efeito colateral é a sensibilidade dentinária após a realização desse procedimento, já que o peróxido de hidrogênio tem pequena massa molecular favorecendo sua difusão pelos tecidos mineralizados até atingir a polpa dental (1). Sendo assim, o presente projeto avaliou os efeitos da incorporação de Hidroxiapatita, ACP e MCF com $\beta$ TCP em um agente clareador à base de peróxido de hidrogênio na alteração de cor, rugosidade e dureza.

\section{Resultados e Discussão}

Quarenta incisivos bovinos foram avaliados quanto à dureza, rugosidade e cor do esmalte. Em seguida, foram submetidos ao clareamento com peróxido de hidrogênio $35 \%$ ou peróxido de hidrogênio $35 \%$ dopado com ACP, HAP ou MCP-TCP. Novas leituras de cor, rugosidade de dureza foram realizadas após 24 horas e 7 dias do término do clareamento. A permeabilidade do esmalte após o clareamento foi avaliada em microscopia confocal de varredura por laser. Os dados foram avaliados com nível de significância de $5 \%$.

Figura 1. Micropermeabilidade por microscopia de varredura confocal por laser.
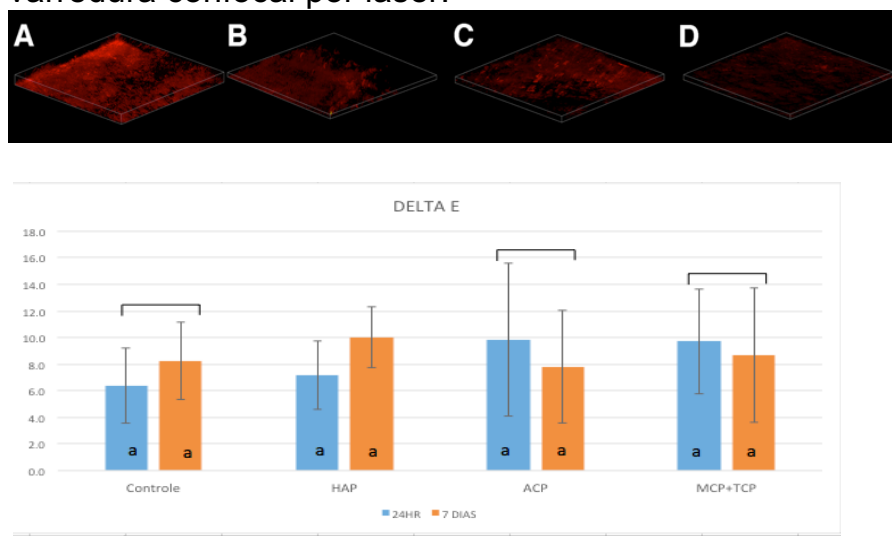

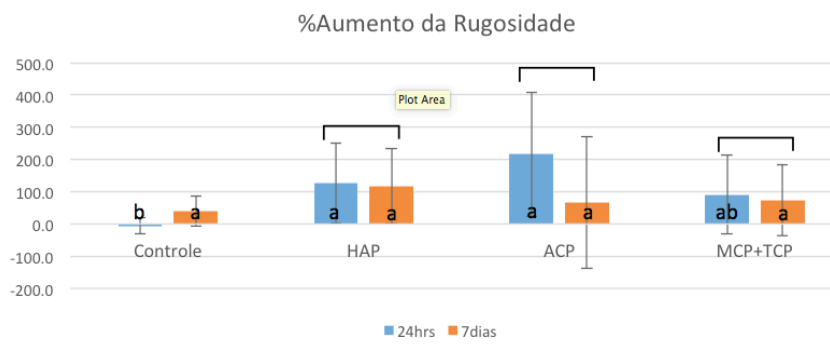

Letras minúsculas distintas representam diferença significativa entre agentes clareadores, dentro de cada tempo. Barras representam ausência de diferença significativa entre os tempos 24 horas e 7 dias.

\section{Conclusões}

Os agentes clareadores dopados com fosfatos de cálcio não inferiram na cor e na rugosidade do esmalte após o clareamento, mas possibilitaram menor redução da dureza causada pelo clareamento.

\section{Agradecimentos}

Agradecimento ao CNPq e ao Centro de Microscopia e Imagem da FOP-Unicamp.

${ }^{1}$ Eimar H, Siciliano R, ABdallah MN, Nader AS, Amin WN, Martinez PP, et AL. Hydrogen peroxide whitens teeth by oxidizing the organic structure. Journal of Dentistry 2012;40:e25-33 